\title{
Waiting for IR Godot? In search of transformative encounters between Middle Eastern Studies and International Relations
}

\author{
Irene Costantini ${ }^{1 \star}$ (D) and Ruth Hanau Santini ${ }^{2}$ (D) \\ ${ }^{1}$ Università L'Orientale, Naples; University of Bologna, Italy and ${ }^{2}$ Università L'Orientale, Naples, Italy \\ *Corresponding author. Email: icostantini@unior.it
}

(Received 13 September 2021; accepted 23 September 2021; first published online 9 November 2021)

\begin{abstract}
Within the Special Issue 'Reaching for allies? The dialectics and overlaps between International Relations and Area Studies in the study of politics, security, and conflicts', this article investigates the post-2011 changing relationship between International Relations (IR) and Middle Eastern Studies (MES). The article departs from the assumption that the reading and writing of security in, on and from the Middle East and North Africa (MENA) region has historically been trapped between the projection of security from abroad and endogenous security narratives. We argue that within the post-Arab uprisings renewed scholarly attention, with studies on security in, on and from the MENA region expressing an all-time methodological pluralism and the increasing and original application of bottom-up and non-military security understandings to regional security, societal and human security are among the most promising notions for transformative dialogue between IR and MES. In broader theoretical terms, we show how the ongoing debate on post-Weberian notions of statehood and post-Westphalian sovereignty point to an already transformative dialogue between IR and MES. The article illustrates this trend with two case studies - on Tunisia and on Iraq - pointing to changing security concepts reflecting changing security practices.
\end{abstract}

Key words: Area studies; international relations; Middle East and North Africa; Middle Eastern Studies; security

\section{Introduction}

Within a special issue dedicated to the dialogue and overlaps between Area Studies and international relations, this article serves the purpose of looking at their relationship from the vantage point of Middle Eastern Studies (MES) and with a focus on security. The choice of such focus is justified by the fact that the Middle East and North Africa (MENA) region, in itself a security-oriented construct (Amanat 2012), has traditionally been at the centre of international efforts at defining and addressing security/insecurity in international politics, albeit different historical periods having looked at security in and from the region in different ways. During the Cold War and in line with its logic, what prevailed, both among policymakers and scholars, was a topdown, outward-oriented and military-focused approach to security guiding the study of, mostly, international conflicts, alliances and military arrangements (Bilgin, 2005, 4). The unipolar moment that followed revised some of the prevalent notion of security and since the turn of the 21st century, there has been a scholarly shift towards more bottom-up, inward-oriented and non-military focused approach in the study of prevailing themes associated with security, now dominated by terrorism, state failure and all its related corollary of poverty, crime and regional conflict.

(C) The Author(s), 2021. Published by Cambridge University Press on behalf of the Società Italiana di Scienza Politica. This is an Open Access article, distributed under the terms of the Creative Commons Attribution licence (https://creativecommons.org/licenses/by/4.0/), which permits unrestricted re-use, distribution, and reproduction in any medium, provided the original work is properly cited. 
This article considers 2011 a critical juncture for analysing changing notions of security in, from and on the MENA region. Domestically, the initially peaceful protests that erupted in Tunisia and Egypt and then spread to Libya, Syria, Yemen and other countries across the region have led to regime change in Tunisia and Egypt, the outbreak of civil conflicts in Yemen, Syria and Libya while they have been coopted and/or repressed in monarchical system where the status quo was thereby preserved, such as in Morocco and Bahrain. Besides amply modifying domestic notions of security, the events since $2010 / 11$ saw international factors becoming key variables to explain regional dynamics and more specifically security trajectories in and of the region, as new interests in the 'second image reversed"1 (Gourevitch, 1978) perspective is showing (see also Lynch, 2021). The year 2011, while in no way a unique occurrence, given the region's deep history of social mobilization and conflicts, did act as a catalyst for an evolving multipolar regional system characterized by, among others, deeply internationalized security, an intensification of threat perceptions and alternative security narratives as exemplified by the debate on sectarianism and sectarianization (Malmvig, 2014; Hashemi and Postel, 2017; Valbjørn, 2017; Mabon, 2020; Pomeps, 2020).

Security in the MENA region has been characterized by several critical junctures: the revolution in Iran in 1979; the 1991 Gulf war; the Iraq war in 2003. Although the extent to which 2011 represented a critical juncture is a matter of debate depending on the themes examined and the disciplinary stand (Bank and Busse, 2021), this article contends that it represented a critical juncture from a security perspective. While the 2010/11 uprisings originated in endogenous dynamics, these domestic trajectories have impacted regional security. The descent into localized civil conflicts turning into regional military confrontations and later into internationalized conflicts has shaken the already fragile post-2003 geopolitical status quo. In parallel, this has brought about a deep rethinking of Middle Eastern regional security studies and of the cognitive structures employed in previous eras to define altogether different phenomena. New studies have articulated debates surrounding notions of regional cold war, new interpretations of proxy wars and of proxy actors, identification of mobilization of identity vs. ideology as enabling factors driving conflict. Scholars have engaged this new empirical material with IR notions, re-interpreting them and applying them to changing regional security dynamics.

The article proposes a reflection on how security has been treated in the last decade in between MES and International Relations (IR) and presents the achievements and limits of this scholarship. It opens by tracing the uneasy relationship between Area Studies and IR for the study of the MENA region. Examining major perspectives on security in and on the region, it then extends the debate on the relationship between IR and Area Studies by taking into consideration categories of traditional security, on the one hand, and human and societal security, on the other hand. To empirically ground the theoretical discussion on security in, on and from the MENA region, the article identifies two post-2011 case studies, one drawn from Maghreb, Tunisia, and one from the Middle East, Iraq. The choice of the case studies is justified by the fact that both countries have undergone regime change, have seen their security sectors - more or less profoundly reformed, have faced terrorism threats, albeit to different degrees, and they illustrate significant instances of shifting concepts and practices of security. These case studies elaborate on the shift between regime, state, societal and human security and how changing understandings reflect changing practices of security.

Overall, the article argues that since 2011 the dialogue between IR and MES has moved another step away from the hierarchical nature it had in the past. Studies adopting traditional notions of security show a tension between, on the one hand, overcoming the universality-particularity divide, and on the other hand, fully exploiting the potential of cross-fertilization between perspectives. While this self-reflexive attitude is welcomed, the article finds nonetheless that the promise of a transformative dialogue between IR and MES lies instead in notions of

${ }^{1}$ The 'second image reversed' looks at international sources of domestic politics. 
human and societal security. MES has waited for IR Godot for decades, expecting a dialogue with International Relations' Theory on an equal footing. While a transformative form of dialogue between the two is not there yet, acknowledging the progress and mutual learning occurred in the past decade suggests Godot might be in sight. The recent turns in IR revolving around hybridity for political systems, limited statehood, flexible understandings of governance configurations in parallel with MES' attention towards the reconceptualization of statehood and security, categorizing the role of non-state actors and the varying governance formats are well-positioned to grasp the empirical particularity within the theoretical universality of these concepts and frameworks.

\section{MES and IR: friends or foes?}

The contentious relationship between MES and IR has a long history. The question is not so much whether there has been a dialogue between these disciplines, but the extent to which the nature and modalities of this dialogue, either eristic (characterized by strife and aimed at reproducing each scholarly identity), hierarchical (based on uneven division of labour in the academic epistemic hierarchy), self-reflexive (reflecting the limit of each field's knowledge) or transformative (when two disciplines merge and create new understandings), have changed through time (Valbjørn, 2017).

In the interwar period, there was an almost neat division of labour between Area Studies and social sciences: the former was expected to collect data based on the deep and multifaceted knowledge of the ground while the latter would have provided explanation for them grounded in universally valid theoretical frameworks (Mitchell, 2004). It was in the 1950s that the crystallization of the dichotomy between Area Studies and social science disciplines was established. In that context, and from then onwards, an epistemic hierarchy formed among disciplines whereby the production and organization of knowledge came to be premised on the binary separation between theoretical-universality on the one hand and empirical and particular on the other (Teti, 2007) - thus, relegating Areas Studies to a hierarchically subordinate position: 'the genealogy of Area Studies must be then understood in relation to the wider structuring of academic knowledge and to the struggles not of the Cold War but of [social science] as a twentieth-century political project' (Mitchell, 2004, 2).

In this long and ever-evolving debate, now considered to be in a second generation phase (Busse, 2018), Area Studies - MES - have been accused of being atheoretical, disjoined from social sciences when it came to methodological rigour and tended to be depicted as an antiquated pursuit (Tessler et al., 1999). In contrast, as underlined by Anderson (1999) in that same volume, insularity was an allegation that could have more easily been addressed to American political science, struggling to appreciate the context-specific nature of many social phenomena, failing to recognize the multilinearity of contemporary political change. If mainstream social science disciplines could be accused of being culture-blind, aiming at producing universal knowledge, Area Studies were accused of being culture-blinded (Valbjorn, 2004), upholding the idea that generalization had its limits. The 1990s Middle East Area Study Controversy (ASC), which originated in the US academic debate, precisely sought to break such boundaries between disciplines, calling for that cross-fertilization that in the early 2000s began to produce its results mostly in Europe and the Middle East (Bilgin, 2004; Valbjørn, 2004; Teti, 2007). In the American academia, the debate has not been revived since the 1990s. There, the combination of 'methodological sophistication with significant field research and language skills', 'the escalating fetishization of method and prioritizing causal inference' and 'changes in the publication expectations and the job market' has considerably reduced the salience of the ASC (Lynch, 2021).

Historically, MES and IR have displayed difficulties in developing fruitful communication (Teti, 2007). The under-developed analytical exchange between MES and IR can be explained by referring to at least three factors. First, while Area Studies do incorporate political science 
concepts and/or theoretical framework, they also focus on issues that have a direct bearing on IR without necessarily displaying concepts or approaches stemming from IR theories. Second, the multidisciplinary nature of Area Studies renders them more scattered and fragmented as a field of study, less parsimonious and not geared towards generalizability. As such, they face more difficulties in summarizing the state of the art, with even significant insights facing challenges in travelling in a transregional way through comparative approaches. Third, most studies produced by area scholars tend to be seen as valid insofar as they test IR theories, corroborate existing approaches or provide new empirical material in support of existing IR theory, as in hierarchical forms of interdisciplinary dialogue. The opposite, the generation of new analytical or theoretical insights travelling from Area Studies to IR has proven more difficult, despite key exceptions (David, 1991; Ayubi, 1995), as have new transformative forms of dialogue generating new insights merging IR and MES. Within Area Studies, then, there is scarce dialogue among scholars working on different regions or eras, which is more pronounced than among scholars from different disciplinary backgrounds.

While the debate between IR and MES continued along these lines, the events of 2011 sparked novel reflection on this divide in Europe and the MENA region. An initial observation pointed to the fact that 'whereas the comparative-politics literature on the Arab uprisings and their aftermath demonstrates theoretical progress with sophisticated empirical analysis, there has been significantly less theoretical engagement by international relations (IR) theorists' (Lynch and Ryan, 2017, 643). Within this general trend, in the ensuing years, there has been an effort to fill this gap, encouraging cross-fertilization between IR and MES to address specific themes, more in the direction of a self-reflexive dialogue, such as regional hegemony (Hinnebusch, 2019), the role of non-state actors in regional politics (Kausch, 2017) or the study of alliances (Darwich, 2021), as well to advance a meta-level reflection on the disciplines (Pomeps, 2015; Fawcett, 2017; Lynch and Ryan, 2017; Stetter, 2021). An effort at cross-fertilization has also been encouraged by the broader debate on the Global, Post-Western, Global South IR, and geo-cultural epistemologies and the loci of knowledge production (Tickner and Waever, 2008; Abboud et al., 2018; Hazbun and Valbjørn, 2018; Acharya and Buzan, 2019). In this temporal and geographical changing IR-MES dialogue, scholarship focused on security has always occupied a central position, displaying some of the tendencies identified above and discussed in more detail in the following sections.

\section{Traditional security: between theoretical reflection and empirical reality}

Since 2011, IR scholarship has been left with the thorny issue of explaining the remarkable changes within the region that occurred beyond the uprisings, particularly with reference to security. Indeed, 'since the Arab Uprisings, Middle East geopolitics has transformed from a system organized around and against a US-managed security architecture into a multipolar system lacking norms, institutions, or balancing mechanisms to constrain conflict and the use of force' (Hazbun, 2019, 14). Within this transformation and the academic debate that sought to grasp it, what security means in the region remains a challenging yet pressing question (Bilgin, 2005, 2015). Over the last 10 years, the debate on security in, on and from the MENA region has seen a resurgence of key security studies' concepts and theoretical approaches - cold war, proxy wars, regional security complex (RSC). In IR and MES security-focused scholarship, be it on post-2011 Libya and Syria, post-2015 Yemen or on the growing tensions between the Islamic Republic of Iran and Saudi Arabia, these concepts and theoretical approaches come with a heavy baggage, having been developed in relation to security dynamics of the past.

The reference to the 'Cold War' in MENA was first employed by Malcom Kerr in the mid-1960s to define the regional balance of power between an anti-status quo republics' socialist camp dominated by the Egyptian president Nasser's soft power and a monarchical conservative camp, spearheaded by Saudi Arabia (Kerr, 1965). The Arab regional cold war reflected the main 
tenets of the broader Cold War in three ways. Firstly, it attributed high significance to ideology as the determining feature distinguishing the two opposing camps and their allies. Secondly, the two regional main powers mostly articulated their antagonism by manipulating regional countries' tensions, waging proxy wars rather than direct military confrontations. Lastly, they shared a zerosum game logic which was premised on the stark opposition between Nasser's raison de la nation arabe and Sunni monarchies' raison d'Etat (Valbjorn and Bank, 2012).

The 1950s-1960s Arab cold war displayed an uncommonly high level of politicization around regional bipolarity: the securitization of ideological values and alliances framed the regional soft power rivalry. Studies, as the one by Kerr, on the specificities of the Arab cold war pointed to counter-intuitive arguments which however remained neglected in mainstream IR and security studies. The 1958-61 period showed the extent to which even during a regional cold war, alliances could shift, and ideological bipolarity be trumped by the sovereignty norm, highlighting the extent of normative fragmentation even at the peak of the bipolar confrontation (Haas, 2014). In that timeframe, the Egyptian unification with Syria took place and got dissolved and the postrevolutionary Iraqi government of Abd al-Karim Qasim, despite ideological proximity to Nasser's pan-Arabism, refused Egyptian tutelage and distanced Iraq from Egypt, weakening the resistance front.

The cold war label and language resurfaced in MES even before 2011, around the implications of two different events: the 2003 Iraq war and the 2006 Israel-Hizbollah conflict. The 2003 Iraq war caused a split in the Arab League, as Gulf powers tacitly agreed with the US military intervention, while Syria publicly criticized the attack. Once again, normative fragmentation led to regional dis-unity and to the deepening of regional fractures. In the wake of regime change, US top-down power-sharing agreements led to an enhanced role by Shia political and security forces, which contributed to the sectarian turn of the Iraq civil war after 2006. The role of the Islamic Republic of Iran in Iraqi politics, both on the state level as well as through support of non-state forces has increased threat perceptions across the Sunni Gulf. Similarly, the crosssectarian regional symbolic and reputational victory by Hezbollah leader Hassan Nasrallah went well beyond Shia and Lebanese audiences and reverberated across the Arab non-Shia world, thereby exacerbating unease and threat perceptions in the Gulf (Valbjorn and Bank, 2007).

The post-2011 revival of the cold war label was employed to describe the growing confrontation between the Islamic Republic of Iran and the Saudi-centred Sunni block. Similar to the past, such revival attributed high significance to ideology (now interpreted almost exclusively in sectarian terms), focused on the geopolitical bipolar rivalry around areas rendered unstable by years of civil wars (i.e., Syria, Libya, Yemen), and emphasized the zero-sum game logic of the contending parties and their allies. However, from a theoretical standpoint, this revival failed to assimilate the insights gathered from post-2003 Iraq and post-2006 Lebanon; without producing concepts able to travel to IR modifying the ways in which 'cold wars' are conceptualized, that is, still embodying a hierarchical dialogic modality. The notions of ideological multipolarity (Haas, 2014), normative fragmentation (Barnett, 1998), determining less rigid alliance patterns and more flexible alignment choices have been largely ignored by mainstream political science literature, which thus has maintained, rather than fill, the gap between IR and MES.

Together with the resurgence of the cold war label, security-oriented scholarship looking at post-2011 arrangements in MENA resurrected the concept of proxy war, employed ubiquitously in the MENA's theatres of war. The overtly state-centric nature of the classical understanding of proxy war provided half a century ago by Karl Deutsch ${ }^{2}$ was corrected by incorporating the role of regional powers and a new appraisal of non-state actors, which coincided with a growing attention towards cases from the MENA region, in what could be understood as a partial overture

\footnotetext{
${ }^{2}$ Karl Deutsch defined proxy wars as an international conflict between two foreign powers, fought out on the soil of a third country, disguised as a conflict over an internal issue of that country, and using some of that country's manpower, resources and territory as a means for achieving preponderantly foreign goals and foreign strategies'(Deutsch 1964, 102).
} 
from IR towards a more self-reflexive dialogic turn. To adapt to a changing reality, Mumford $(2013,1)$ defined proxy war as 'indirect engagement in a conflict by third parties wishing to influence its strategic outcome' through the provision or training of manpower such as co-opted militias or other irregular combatants, the provision of material or money or the sharing or dissemination of information'. This forward-looking gaze also identified as features of evolving practices of proxy wars the role of regional powers and (in)formal 'proxy coalitions' of both state and non-state actors (Mumford, 2013, 8). These revised notions of proxy wars have been employed, for instance, in the case of post-2011 Syria by MES scholars (Phillips and Valbjorn, 2018; Leenders and Giustozzi, 2019) which have problematized proxy war by pointing to first, the multiplicity of proxy wars (as in the Syrian case) and the different logics of mobilization used by regional and global powers with local proxies (national, religious/sectarian, ethnic). The role of the multiplicity of identity referents that can be effectively mobilized and acted upon in a military confrontation is, once again, empirically demonstrated by MES but so far failed to make inroads into broader IR rethinking on proxy wars, a testament to the ongoing challenge of generating a truly transformative dialogue.

With the post-uprisings' militarized trajectories in Libya and Syria, reference to a regional cold war has come to imply a broader front where multiple state and non-state actors have penetrated countries outside of their sub-regional complex or even outside of their region. RSC theory is another theoretical concept which has featured across Area Studies in the past few decades and has, time and again, partially been revised, without however taking into account suggestions/insights/theorization coming from Area Studies or MES in particular. RSCs are 'sets of units whose major processes of securitization, de-securitization or both are so inter-linked that their security problems cannot be reasonably analyzed or resolved apart from one another' (Buzan and Weaver, 2003, 43-45). The key elements at the basis of any RSC are three sets of dichotomies, in addition to power distribution among actors: anarchy vs. integration (polarity), amity vs. enmity (relations among units) and securitization vs. de-securitization (processes of threat construction). What this approach allows to capture are the ways in which perceptions structure socially constructed relations among regional actors, thereby being at the core of regional order configurations.

In the past few years, this approach has been applied to the changing regional geopolitical constellations in the MENA region, with some analytical innovations. On the one hand, the rationalist-realist binary separation between anarchy and integration has been challenged and a third multilayered notion has been proposed, heterarchy. Heterarchy has been recently introduced in IR (Donnelly, 2009, 2016) and had not until lately made incursions into MES. Heterarchy introduces a third ordering principle beyond hierarchy and anarchy, it emphasizes the role of sub-national, transnational and international actors - even in processes of fragmentation of the existing political order - and accepts more blurred lines between the reciprocal influences of the domestic and regional levels. Heterarchical orders refer to systems with multiple and often 'tangled' hierarchies.

The heterarchic notion of multiple rankings of power relations is useful in the analysis of increasingly hybrid MENA political systems, where rather than weak statehood or multiple governance arrangements, war orders can be conceptualized as heterarchic orders of agencies of coercion whereby stateness is flexible (Leenders and Giustozzi, 2019) but also to regional orders (Hanau Santini, 2017; Hinnebusch, 2018). These applications to the MENA context have on the one hand deepened the previously under-developed IR application notion of heterarchy as a specific regional order premised neither on hierarchy nor anarchy. They have also debunked once for all ill-suited IR accounts of the MENA regional order as essentially anarchic. Moreover, given the high penetration between states and societies in the region and the frequency of domestic concerns impinging on foreign policy choices - what has been termed omnibalancing by David (1991), heterarchy remains an under-utilized concept in MES, but the innovations derived from its empirical usage have far from been incorporated into IR. 
Whether it is the debate around the Arab Cold War, proxy wars or RSC and its innovations, recent scholarship testifies to a tension between, on the one hand, overcoming the universalityparticularity divide, and on the other hand, fully exploiting the potential of cross-fertilization between perspectives. The dialogue between IR and MES scholarship, taking as a standpoint traditional notions of security, can be thus described as self-reflexive, engaging with the limits of each field's knowledge without yet producing an altogether new understanding as a result of a deeper merge or cross-fertilization of disciplines.

\section{Human and societal security: between theoretical reflection and empirical reality}

Zooming in more closely on changing theoretical approaches of security and their capacity to testify to changing practices, more than two decades have passed since the concept of human security first emerged and revolutionized the way in which security is thought and practiced. This notion was developed in the aftermath of the end of the Cold War, when it became imperative to broaden security recipients beyond statist categories. Analytically disentangling security from the state as sole security referent implied problematizing security and answering the 'security for whom' question. Human security enlarged and deepened notions of security beyond a rigid state-centred, top-down and military-oriented perspective. A people-centred approach allowed to consider new issues and aspects, such as the economic drivers of insecurity as well as environmental ones, which are proving essential to account for contemporary challenges to the MENA region and beyond (Korany, 1986; Korany et al., 1993; Jacoby and Sasley, 2002). Besides human security, societal security conceptualizes security through the lenses of society, deemed to be about collective identity, that is, the self-conception of community, which, far from being static or reification of individual identity, is processual, fluid and constructed. Ole Waever refers to fear for the survival of culture, community, nation and religion as examples of security understandings in terms of identity (Waever, 2008). Societal security, rather than being issue-driven (economic, environmental, physical, etc.) revolves around the sense of identity security for a community, the perception that a specific way of life can be preserved from external threats.

A human security-centred perspective informed different developments in the analyses of security dynamics in the MENA. To begin with, a wide range of scholarship has questioned the concept of the state, mostly in relation to the post-2011 conflicts in Libya, Yemen, Syria as well as Iraq, but not only. This scholarship has taken up the widespread criticism towards the prevailing notions of weak, fragile and failed states and applied to the MENA region. What emerges is a regional perspective that moves beyond a Weberian and Westphalian approach to the state highlighting that if claims to a monopoly of legitimate violence are challenged and/ or violence is exerted by several categories of actors, many of them non-state, the statehood paradigm cannot but appear as a seriously ill patient' (Hanau et al., 2021, 2).

Attempts at overcoming the state as the main referent to as well as the main agent of security are informed by different theoretical frameworks. Hanau et al. (2021) try to assess the validity of the limited statehood framework in their collection dedicated to the study of the creation of different security orders across the Middle East and Africa. From a similar perspective, other studies have examined fragmented and overlapping systems of governance, the permeability and rearticulation of borders, the incidence of transnational movements and their impact on the state as an analytical category guiding studies in and on the MENA (Clausen, 2018; Costantini, 2018; Doyle and Dunning, 2018; Droz-Vincent, 2018; Hinnebusch, 2018). Other studies, often informed by an anthropological view on the state, have added to the debate by rejecting the state as 'an $a$ priori conceptual or empirical object' (Sharma and Gupta, 2006, 8) and looking instead at its effects and ways in which the state is imagined by the people (Hermez, 2015; Mouawad and Baumann, 2017).

Linked to the above is also the growing attention towards non-state actors in security/insecurity dynamics. Once the rigidities of the state as an analytical object are loosened, the MENA 
region is exemplary (but not exceptional) in the heterogeneity of non-state actors' structures, objectives, source of legitimacy, use of violence and means of financing. This trait, already explored for instance in relation to the state-like character of organizations like Hamas and Hezbollah, has been reflected in the multiplication of studies following the derail of the Arab uprisings. Scholars have explored state-like or state-aspiring entities, such as the Kurdistan Region of Iraq, the Southern movement in Yemen, or the Islamic State; armed non-state actors, including pro-government militias; as well as transnationalism (Ahram, 2019; Revkin and Ahram, 2020). Scholarship on non-state actors in the MENA region has extensively covered their dual position in governance structures: 'non-state actors erode state control and, above all, the monopoly over the legitimate use of violence, but simultaneously fill governance gaps, ranging from service to security provision' (Costantini, 2016, 417), pointing to their evolving position in society as well as in international politics.

To make sense of the overlapping, at times alternative and at times convergent role of state and non-state actors in governance and in security, scholarship in, on and from the MENA region has resorted to the lens of hybridity. Hybridity is neither new - it has been widely discussed in the literature on democracy and development (Roberts, 2013,94) as well as on peace and conflict studies (Boege et al., 2009; Boege, 2019) - nor univocal. Its adoption points to the coexistence of different and competing socio-political orders, which is interpreted as a contextual condition of fluid exchange and contamination. Although the criticism over its analytical fuzziness, complex applicability, and significance, hybridity strikes for its empirical validity whether it is employed to explore armed groups in Libya, Yemen, Syria, Iraq as well as security dynamics beyond these conflict-affected contexts (Sayigh, 2018; Ahram, 2020; Ardemagni et al., 2020; Badi, 2020). Similar to hybridity, assemblage thinking is mostly descriptive but is gaining attention in critical security studies, both in general and in those applied to the MENA region (Tholens, forthcoming). Assemblage thinking is premised on a relational ontology and focuses on the making and un-making of a complex global process where state, non-state, public and private actors interact and create new arrangements (Acuto and Curtis, 2014; Savage, 2019). In particular, according to Abrahamsen and Williams (2009), global security assemblages are based upon a constant shift between assembling and reassembling of knowledges and practices. Assemblages include notions of 'networked governance'; shifting norms or 'mentalities' of security; and increasing salience of risk-based security thinking and technology (3).

When these insights are taken into consideration, human security provides for a theoretical contribution that accounts for the shifting security notions and practices at different levels and across actors. Societal security adds to this by incorporating security within a community and considering identity besides other drivers of security/insecurity dynamics. These concepts are essential to orient analyses that treat security in a relational perspective capable of capturing not only the distinction between security arrangements and interpretations (international, state, regime, societal, human and societal security), but also their relationship. Both perspectives are ways to lay claim to bottom-up understanding of security despite setbacks. Notably, the notion of human security as the concept informing the norm of the Responsibility to Protect declined after it became exposed to the manipulation of international actors pursuing nonhumanitarian consideration following its inclusion in the UNSC resolution 1973 (2011) authorizing the NATO-led Operation in Libya (Bellamy and Williams, 2011). The following case studies serve precisely to illustrate empirically how shifting security notions and practices in the contexts of Tunisia and Iraq and their interactions render the security domain in ways that can be hardly explained by traditional concepts and theoretical framework.

\section{Ben Guerdane, or the battle enabling shifting security notions in Tunisia}

On 7 March 2016, a group of 50 armed ISIS militants attacked Ben Guerdane, a small southern Tunisian city on the borders with Libya. The assault was warded off by the army and security 
forces with the support of local residents following a fierce battle. Had the attack been successful, Ben Guerdane would have become the first base of the Islamic Caliphate in Tunisia. This dramatic event was noteworthy as it signalled a new degree of successful cooperation between the various security forces, but also, and more importantly for the paradigmatic changes in security understandings, between security forces and border citizens, traditionally caught between resistance and repression. The active collaboration of local residents defending the town of Ben Guerdane, their community and their way of living against an imminent external threat, embodied changing security practices illustrating changed notions of security.

The pre-revolutionary regime security understanding was centred around president Ben Ali, his family and clan and their interests (Hibou, 2006). Any threat to the survival of the leader and his immediate circle was deemed a national security threat, without however necessarily posing an existential threat to the country itself. With the 2010/11 uprisings and the postrevolutionary transition, security became strictly associated to the state, as testified when the country faced terrorist threats, both in 2013, with the two rounds of political assassinations, and in 2015, when ISIS-led attacks risked derailing the political trajectory and plunge the country into chaos (Hanau Santini, 2018). At the forefront of this reading of security were territorial integrity, control over terrorist groups' activities, political neutrality in border countries' uprisings or conflicts.

Since the demise of the regime, the discourse about security shifted towards state security notions of territorial integrity and state sovereignty, especially vis-à-vis the threat coming from Libya and its post-Qaddafi destabilization. With the episode of Ben Guerdane in 2016, the understanding of security further shifted, and its security referents were broadened. The key role of local residents shielding security forces, protecting them, helping them and contributing to win the battle offered new analytical and symbolic elements enabling the discursive shift from state to societal security. This was particularly relevant as it reversed decades of dismissive and pejorative discourse of southern populations deemed anti-colonial and disloyal to the postindependence statist project (Mullin and Rouabah, 2018; Simoncini, 2021). Defending the city was as much about defending the integrity of the country from the risk of an Islamist takeover, as protecting a community and its way of life.

Ben Guerdane had historically been stigmatized as a community thriving thanks to economically illicit practices of cross-border smuggling with Libya and considered a potential hotbed for radicalization and political violence. The flourishing of informal economic activities in culturally, politically and economically marginal areas was a reaction to the postcolonial political geography of disinvestment and to the nationalist identity spearheaded by the Bourguibist statist project (Bono et al., 2015). These forms of informal political economy were a response to human security needs that were neglected by the central authority, which conveniently depicted the south as a secessionist and backward exception to the rest of the country. In the eyes of Tunis-based politicians and national media, the 2016 battle came to symbolize its moral and social redemption. The bravery not just of security forces but of the local population has since then become a standard reference in the public discourse, partially aimed at reshaping the image of previously socially and culturally marginalized local residents now heralded as the symbol of national virtues and merits and symbolizing the ideal type of brave new Tunisians fiercely defending their homeland (Hanau Santini, forthcoming). The driver for the collective acts of self-sacrifice by local residents was not heroism or ideological proximity with the state or the security forces, but rather the need to preserve their community's societal security.

The March 2016 attacks served as a focal point exemplifying the dangers faced by the community's collective identity. In several interviews conducted by one of the authors in Ben Guerdane in November 2019 with members of the local community, there was a pointed reference to identity dimensions which went beyond the individual level and encompassed the sense of a community identity and the need to preserve it ('we are not like them, we have nothing to do with terrorists', 'they would have changed how we live', 'they were alien, different from us, also the 
ones from Ben Guerdane, they came from Libya'). This narrative about an external threat, not merely to physical survival but to community values and way of life, points to an acknowledgement of a specific system of values in societal security terms. From the side of the community, in other words, it was societal security that drove individual and collective responses (acting as human shields for police agents; denouncing exact locations of terrorists; refusing to embrace arms when asked by terrorists). In a way, that episode became a defining moment for the community to draw a line of what it stood for (rejection of political violence and the use of arms) and of the changing notion of security it felt was representative of their community.

\section{Defending what and whom? The Hashd al-Shaabi in the Iraqi security scenario}

The Hashd al-Shaabi (Popular Mobilization forces) is an umbrella organization grouping together a highly diversified and decentralized group of established and newly created militias, only loosely coordinated within the Popular Mobilization Commission and responding to different command lines, of a tribal, political and/or ethnic nature, totalling around 30-50 groups and 150,000 members (O’Driscoll and Van Zoonen, 2017; Ezzedine et al., 2019). The genesis of the Hashd al-Shaabi is found in the expansion of the Islamic State that in June 2014 managed to conquer a large swathe of Iraqi territory, including the second largest city in the country, Mosul, and threatening to conquer Erbil in the Kurdistan Region of Iraq and Baghdad. The alternative notion of the state emphatically stressed by the Islamic State (i.e., drawing new state boundaries between Iraq and Syria; articulating new forms of religiously-oriented authority and proposing an altogether alternative model of governance) urged an initial reaction framed around the notion of state security, which also acted as a glue that held together a diverse set of actors, including the International Coalition to Defeat ISIS, the Iraqi Security Forces, the Peshmerga and the Hashd al-Shaabi.

The trajectory of the Hashd al-Shaabi following the defeat of the Islamic State in Iraq in late 2017 shows however the demise of state security as the overarching understanding of security in the country and its collusion with alternative security notions. Indeed, the defeat of the Islamic State did not lead either to the demobilization of the group or a process of reintegration into the formal security apparatus. While various attempts have been formally made to sanction the existence and operation of the Hashd al-Shaabi, some of them have maintained separate lines of command and structure as well as undertook independent actions at times contrary to the Iraqi government's interpretation of national security (Knights et al., 2020). Among them stand the what is often referred to as the 'resistance formation' ( fasa'il al-muqawamma), a group of militias and militiamen whose relationship with Iran (in terms of sponsorship as well as of a model of political organization) determines their controversial position within the Iraqi security apparatus (Haddad, 2020).

If the Hashd al-Shaabi have been fundamental to defend state security at the time of the expansion of the Islamic State, they soon positioned themselves into an ambiguous position in between national security and regime security. In particular, the 'resistance formation' has upheld an interpretation of security that collapses state security with regime security, which is primarily interpreted through the lens of ethno-sectarianism. In the eyes of part of the Iraqi leadership and public, they became the necessary force for the security of the post-2003 Shia-centred regime. The complementarity reached by formal and informal security providers that proved successful to react to the IS insurgency since 2014 transformed into a rivalry that sets apart different visions of the state, continuing a trend already evident in the aftermath of the invasion and occupation of the country in 2003 (Costantini, 2018). In parallel, this extended to notions of regional security: the growing tension between the US and Iran reached its apex with the killing of Qasem Suleimani - commander of the Iranian Quds Force - and Abu Mahdi al-Muhandis - the commander of the Hashd al-Shaabi by the US on 2 January 2020. In reaction to that, some of the Shia militias carried out a number of attacks throughout 2019-20 on US personnel and facilities in the country. 
Based on non-overlapping and at times conflicting notions of state and regime security, the Hashd al-Shaabi also represents an ambiguous actor in a diversified understanding of human and societal security. At the individual level, they add up to existing economic and environmental security challenges preventing a restoration of social cohesion in the country. At the community level, as some non-state armed groups assumed a political dimension either at the national or at the local level, they have become a source of or a threat to security based on differently defined in-group and out-group logics. The governorate of Nineveh, the most afflicted by the expansion of the Islamic State, is indicative of this process: there, the threat posed by the Islamic State to eradicate the cultural/religious diversity of the governorate has been met by a process of militarization of society whereby communities have taken up security roles as a function of preserving their existence and their identity in the country. In a localized articulation of the security dilemma, ethno-religious communities' perceptions of security reliant upon non-state security provision have contributed to maintain a high level of insecurity at the governorate level.

\section{Conclusion}

The two case studies of Tunisia and Iraq speak differently to the way in which state, regime, human and societal security-based perspective allows for grasping the differentiated and multilayered articulation of security in space, time and according to the actors involved. They are evidence of the endogenous security narratives that have been largely marginalized, if not altogether ignored by the prevailing view, especially with reference to terrorism and the fight against it, of projecting security from abroad. What the cases reveal is the disarticulation of security from the state, which in turn, feeds into the literature problematizing security together with the state, nonstate actors and their relations. In all, they testify to the pluralization of the understandings and the practices of security and to the contradictions that arise when different dimensions of security are taken into consideration.

What security is and means is subject to change throughout time, geographical space and what is ultimately considered the object of security. The reading and writing of security on the MENA region have been increasingly challenged by accounts from a twofold source. On the one hand by Area Studies' scholars who have enriched existing understandings of IR notions and concepts by showing how their illustrations adapted to MENA contexts could further challenge and/or enrich them. On the other, from MENA scholars writing from the region on the region, rejecting perceived mainstream Western political science and IR approaches and adopting more localized readings, historically contingent approaches and expressing positionality driven concerns.

This article has uncovered some problematic aspects related to how knowledge is produced in, on and from the MENA region. It illustrated the long-standing Area Studies-IR controversy from the standpoint of MES and the different sources of miscommunication and misunderstandings between the two and perceived neglect by MES of IR, a Godot MES has long been waiting for. With this debate on the background and focusing on the theme of security, the article explored key IR-derived concepts - cold war, proxy war - and theoretical approaches - RSC, heterarchy - and has shown the extent to which their application by MES scholars in the past decade to the regional conflict and new patterns in regional order dynamics, beyond enriching understanding of local and regional dynamics, has innovated and partially revised those same IR concepts. At the same time, it has shown the difficulties for these revised approaches to travel back to IR or Security Studies, pointing to the continuing insularity of mainstream political science vis-à-vis Area Studies.

On a more positive note for the cross-fertilization between IR and MES, the article noted instead that the recent turns in IR revolving around hybridity for political systems, limited statehood, flexible understandings of governance configurations, as well as notions such as global assemblages internationally run in parallel with MES' attention towards the reconceptualization of statehood and security, categorizing the role of non-state actors and the varying governance formats. As the case studies show, terrorism and the fight against it in the case of Tunisia and 
the role of militias in the case of Iraq are inserted in a broader scenario whereby shifting notions of security (temporal, geographical and actor-based) determine much of the security dynamics in the two countries. The case studies have illustrated how more nuanced and overlapping security understandings can become prevalent, with traditional notions of regime and state security being juxtaposed with new narratives articulated around notions of both human and societal security. The encounter of these two turns in IR and MES is seen as one of great potential to pave the way for an enhanced dialogue between disciplines, which may lead IR to, sooner or later, incorporate some Area Studies' insights so as to strengthen the more transformative dialogue between the two. The wait for Godot, while still ongoing, might not last forever.

Funding. The research received no grants from public, commercial or non-profit funding agency.

Acknowledgements. The authors would like to express their gratitude to the two anonymous reviewers whose constructive and engaging feedback has led to a significant improvement in the quality and originality of the article.

\section{References}

Abboud S, Dahi OS, Hazbun W, Grove NS, Hindawi CP, Mouawad J and Hermez S (2018) Towards a Beirut school of critical security studies. Critical Studies on Security 6, 273-295.

Abrahamsen and Williams MC (2009) Security beyond the state: global security assemblages in international politics. International Political Sociology 3: 1-17.

Acharya A and Buzan B (2019) The Making of Global International Relations: Origins and Evolution of IR at Its Centenary. 1st Edn. edn, Cambridge: Cambridge University Press.

Acuto M and Curtis S (2014) Assemblage thinking and international relations. In Reassembling International Theory: Assemblage Thinking and International Relations. London: Palgrave, pp. 1-15.

Ahram AI (2019) Break All the Borders: Separatism and the Reshaping of the Middle East. New York, NY: Oxford University Press.

Ahram AI (2020) 'Hybrid security, frozen conflicts, and peace in MENA'. In MENA's Frozen Conflicts, 10-14. Pomeps Studies 42. Washington DC: Pomeps.

Anderson L (1999) 'Politics in the Middle East: opportunities and limits in the quest for theory'. In area studies and social science: strategies for understanding Middle East Politics, edited by Mark A. Tessler, Jodi Nachtwey, and Anne Banda, 1-10. Indiana Series in Middle East Studies. Bloomington: Indiana University Press.

Amanat A (2012) Introduction: is there a Middle East? Problematizing a virtual space. In Bonine ME, Amanat A and Gasper ME (eds) (2012) s There a Middle East? The Evolution of a Geopolitical Concept. Stanford, California: Stanford University Press, 1-11.

Ardemagni E, Nagi A and Transfed M (2020) 'Shuyyukh, policemen and supervisors: Yemen's competing security provides'. ISPI and the Carnegie Middle East Center.

Ayubi N (1995) Over-Stating the Arab State. Politics and Society in the Middle East. London and New York: I.B. Tauris.

Badi E (2020) Exploring Armed Groups in Libya: Perspectives on SSR in a Hybrid Environment. Geneva: DCAF - Geneva Centre for Security Sector.

Bank A and Busse J (2021) MENA political science research a decade after the Arab uprisings: facing the facts on tremulous grounds. Mediterranean Politics, Published online: 22 February 2021, 1-24. https://doi.org/10.1080/13629395.2021. 1889285.

Barnett M (1998) Dialogues in Arab Politics. Negotiations in Regional Order. Cambridge: Cambridge University Press.

Bellamy AJ and Williams PD (2011) The New politics of protection? Côte d'Ivoire, Libya and the responsibility to protect. International Affairs 87, 825-850.

Bilgin P (2005) Regional security in the Middle East: a critical perspective. Routledge Curzon Advances in Middle East and Islamic Studies 5. London; New York: Routledge.

Bilgin P (2015) One model of engagement between MES and IR. In Pomeps (ed). International Relations Theory and a Changing Middle East. Washington, DC: Pomeps, 6-12.

Boege V (2019) State formation in the context of hybrid political orders. In Lemay-Hébert N (ed.), Handbook on Intervention and Statebuilding. Cheltenham, UK; Northampton, Massachusetts: Edward Elgar Publishing, 113-123.

Boege V, Brown A, Clemens K and Nolan A (2009) On hybrid political orders and emerging states: what Is failing - states in the Global South or research and politics in the West? Berghof Research Center for Constructive Conflict Management: Berghof Handbook Dialogue No. 8, 1-21.

Bono I, Hibou B, Meddeb H and Tozy M (eds) (2015) L'Etat d'injustice au Maghreb. Maroc et Tunisie. Paris: Karthala.

Busse J (2018) The area studies controversy revisited. APSA MENA Newsletter 5, 29-33. Available at http://web.apsanet.org/ mena/wp-content/uploads/sites/6/2018/11/APSA_MENA_Newsletter_Fall_2018._Final.02.pdf. 
Buzan B and Weaver O (eds) (2003) Regions and Power: The Structure of International Security. Cambridge: Cambridge University Press.

Clausen M-L (2018) Competing for control over the state: the case of Yemen. Small Wars \& Insurgencies 29, 560-578.

Costantini I (2016) Conflict dynamics in post-2011 Libya: a political economy perspective. Conflict. Security \&Development 16, 405-422.

Costantini I (2018) Statebuilding in the Middle East and North Africa: The Aftermath of Regime Change. London and New York: Routledge.

Darwich M (2021) Alliance politics in the post-2011 Middle East: advancing theoretical and empirical perspectives. Mediterranean Politics, published online: 23 February 2021, 1-22. https://doi.org/10.1080/13629395.2021.1889300.

David S (1991) Explaining third world alignment. World Politics 43, 233-256.

Deutsch K (1964) External involvement in internal wars. In Eckstein H (ed.) Internal War: Problems and Approaches. New York, NY: Free Press of Glencoe, 100-110.

Donnelly J (2009) Rethinking political structures: from 'ordering principles' to 'vertical differentiation' - and beyond. International Theory 1, 49-86.

Donnelly J (2016) The heterarchic structure of twenty-first century international governance. Korean Journal of International Studies 14, 1-29.

Doyle D and Dunning T (2018) Recognizing fragmented authority: towards a post-Westphalian security order in Iraq. Small Wars \& Insurgencies 29, 537-559.

Droz-Vincent P (2018) Competitive statehood in Libya: governing differently a specific setting or deconstructing its weak sovereign state with a fateful drift toward chaos? Small Wars \& Insurgencies 29, 434-455.

Ezzedine N, Sulz M and van Veen E (2019) 'The Hashd Is Dead, Long Live the Hashd!' CRU report. The Hague: Clingendael Institute, Conflict Research Unit. Available at https://www.clingendael.org/pub/2019/the-hashd-is-deadlong-live-the-hashd/.

Fawcett L (2017) 'The Middle East in the international system: improving, understanding and breaking down the international relations/area studies divide', Working Paper. Institute for Middle East and Islamic Studies, Durham.

Gourevitch P (1978) The second image reversed: the international sources of domestic politics. International Organization 32, 881-912.

Haas M (2014) Ideological polarity and balancing in Great Power politics. Security Studies 23, 715-753.

Haddad F (2020) Iraq's popular mobilization units: a hybrid actor in a hybrid state. In Day A (ed.), Hybrid Conflict, Hybrid Peace: How Militias and Paramilitary Groups Shape Post-Conflict Transitions. New York: United Nations University, Centre for Policy Research, 30-75.

Hanau-Santini R (forthcoming) Changing security dynamics in Tunisia: reconsidering the battle for Ben Guerdane. In Zayani M (ed.), Tunisia in the Aftermath of the Arab Uprisings. Hurst Publishers.

Hanau S, Abel Polese R and Kevlihan R (eds) (2021) Limited Statehood and Informal Governance in the Middle East and Africa. Durham Modern Middle East and Islamic World. Abingdon, Oxon; New York, NY: Routledge.

Hanau Santini R (2017) A new regional cold war in the Middle East and North Africa: regional security complex theory revisited. The International Spectator 52, 93-111.

Hanau Santini R (2018) Limited Statehood in Post-Revolutionary Tunisia. Political, Economy, Security. London: Palgrave.

Hashemi N and Postel D (eds) (2017) Sectarianization: Mapping the New Politics of the Middle East. London: Hurst \& Company.

Hazbun W (2019) 'In America's wake: turbulence and insecurity in the Middle East'. In Shifting Global Politics and the Middle East, 14-17. Pomeps Studies 34. Washington DC: Pomeps.

Hazbun W and Valbjørn M (2018) The making of IR in the Middle East: critical perspectives on scholarship and teaching in the region. APSA-MENA Newsletter 5(Fall), 5-9. Available at web.apsanet.org/mena/wp-content/uploads/sites/6/2018/11/ APSA_MENA_Newsletter_Fall_2018._Final.02.pdf.

Hermez S (2015) When the state is (n)ever present: on cynicism and political mobilization in Lebanon: when the state is (n) ever present. Journal of the Royal Anthropological Institute 21, 507-523.

Hibou B (2006) La Force de L'obéissance. Economie Politique de la Répression en Tunisie. Paris: La Découverte.

Hinnebusch R (2018) From Westphalian failure to heterarchic governance in MENA: the case of Syria. Small Wars \& Insurgencies 29, 391-413.

Hinnebusch R (2019) The Arab uprisings and regional power struggle. In Akbarzadeh S (ed). Routledge Handbook of International Relations in the Middle East. Oxon and New York: Routledge, 110-124.

Jacoby TA and Sasley BE (eds) (2002) Redefining Security in the Middle East. New Approaches to Conflict Analysis. Manchester: Manchester Univ. Press.

Kausch K (2017) State and non-state alliances in the Middle East. International Spectator 52, 36-47.

Kerr M (1965) The Arab Cold War, 1958-1964: A Study in Ideology in Politics. London, New York, Toronto: Oxford University Press.

Knights M, Malik H and Al-Tamimi AJ (2020) Honored, Not Contained. The Future of Iraq's Popular Mobilization Forces. Washington, DC: The Washington Institute for Near East Policy.

Korany B (1986) Strategic studies and the third world: a critical evaluation. International Social Science Journal 110, 547-562. Korany B, Noble P and Brynen R (1993) The Many Faces of National Security in the Arab World, New York: St. Martin's Press. 
Leenders R and Giustozzi A (2019) Outsourcing state violence: the national defence force, 'stateness' and regime resilience in the Syrian war. Mediterranean Politics 24, 157-180.

Lynch M (2021) Taking stock of MENA political science after the uprisings. Mediterranean Politics, February, published online: 22 February 2021, 1-14. https://doi.org/10.1080/13629395.2021.1889287.

Lynch M and Ryan CR (2017) Introduction. PS: Political Science \& Politics 50, 643-646.

Mabon S (2020) Houses Built on Sand Violence, Sectarianism and Revolution in the Middle East. Manchester: Manchester University Press. Available at https://openresearchlibrary.org/viewer/1aa62824-a996-4c5a-8cee-da6261f832b4.

Malmvig H (2014) Power, identity and securitization of the Middle East: regional order after the Arab uprisings. Mediterranean Politics 19, 145-148.

Mitchell T (2004) The Middle East in the past and future of social science. In Szanton DL (ed.), The Politics of Knowledge: Area Studies and the Disciplines. Berkeley: University of California Press, 74-118.

Mouawad J and Baumann H (2017) Wayn Al-Dawla: locating the Lebanese state in social theory. Arab Studies Journal 25, 66-90.

Mullin C and Rouabah B (2018) Decolonizing Tunisia's border violence: moving beyond imperial structures and imaginaries. Viewpoint magazine. Last Accessed on June 7th 2020 at Available at https://www.viewpointmag.com/2018/02/01/ decolonizing-tunisias-border-violence-moving-beyond-imperial-structures-imaginaries/.

Mumford A (2013) Proxy Warfare. Cambridge: Polity.

O'Driscoll D and Van Zoonen D (2017) The Hashd al-Shaabi and Iraq: sub-nationalism and the state. MERI Report. Erbil: Middle East Research Institute.

Phillips C and Valbjorn M (2018) 'What Is in a Name?': the role of (different) identities in the multiple proxy wars in Syria. Small Wars and Insurgencies 29, 414-433.

Pomeps (ed.) (2015) International relations theory and a changing Middle East. POMEPS Studies 16.

Pomeps (ed.) (2020) 'Sectarianism and international relations'. Pomeps Studies 38. Washington DC: Pomeps.

Revkin MR and Ahram AI (2020) Perspectives on the rebel social contract: exit, voice, and loyalty in the Islamic state in Iraq and Syria. World Development 132, 104981.

Roberts D (2013) Hybrid polities and post-conflict policies. In Chandler D and Sisk TD (eds), Routledge Handbook of International Statebuilding. London and New York: Routledge, 94-105.

Savage GC (2019) What is policy assemblage?. Territory, Politics, Governance 8, 319-335.

Sayigh Y (2018) Hybridizing security: armies, militias and constrained sovereignty. In Sayigh Y and Ardemagni E (eds), Hybridizing Security: Armies and Militias in Fractured Arab States. ISPI and Carnegie Middle East Centre. Available at https://carnegie-mec.org/2018/10/30/hybridizing-security-armies-militias-and-constrained-sovereignty-pub-77597, 1-4.

Sharma A and Gupta A (eds) (2006) The Anthropology of the State: A Reader. Blackwell Readers in Anthropology 9. Malden, MA; Oxford: Blackwell Pub.

Simoncini G (2021) Beyond the Epopee of Ben Guerdane: exploring the plurality of resistance at the south-eastern Tunisian border. Studi Magrebini 19, 88-109.

Stetter S (2021) The Middle East in global modernity: analytic polycentrism, historic entanglements and a rejuvenated area studies debate. Mediterranean Politics, published online: 16 February, 1-25. https://doi.org/10.1080/13629395.2021.1889301.

Tessler MA, Nachtwey J and Banda A (eds) (1999) Area Studies and Social Science: Strategies for Understanding Middle East Politics. Indiana Series in Middle East Studies. Bloomington: Indiana University Press.

Teti A (2007) Bridging the Gap: IR, Middle East studies and the disciplinary politics of the area studies controversy. European Journal of International Relations 13, 117-145. https://doi.org/10.1177/1354066107074291.

Tholens $\mathbf{S}$ (forthcoming) Knowledge, networks and practices of intervention: assembling security force assistance in Lebanon. Journal of Intervention and Statebuilding, 2021.

Tickner AB and Waever O (eds) (2008) International Relations Scholarship Around the World. London and New York: Routledge.

Valbjorn M (2004) Toward a 'Mesopotamian turn': disciplinarity and the study of the international relations of the Middle East. Journal of Mediterranean Studies 14, 47-75.

Valbjorn M (2017) Strategies for reviving the international relations/Middle East nexus after the Arab uprisings. PS, Political Science \& Politics 50, 647-651. https://doi.org/10.1017/S1049096517000312.

Valbjorn M and Bank A (2007) Signs of a new Arab cold war: the 2006 Lebanon war and the new Sunni-Shia divide. Middle East Report (MERIP) 37, 6-11.

Valbjorn M and Bank A (2012) The New Arab Cold War: rediscovering the Arab dimension of Middle East regional politics. Review of International Studies 38, 3-24.

Weaver O (2008) The changing agenda of societal security. In Gunther Brauch H, Oswald Spring U and Mesjasz C (eds), Globalization and Environmental Challenges. Reconceptualising Security in the 21st Century, Berlin: Springer, 581-593.

Cite this article: Costantini I, Hanau Santini R (2022). Waiting for IR Godot? In search of transformative encounters between Middle Eastern Studies and International Relations. Italian Political Science Review/Rivista Italiana di Scienza Politica $\mathbf{5 2}$ 203-216. https://doi.org/10.1017/ipo.2021.48 